\title{
The New Normal Leadership: How Technology Alter Communication Style in Contemporary Organization
}

\author{
http://dx.doi.org/10.25008/jkiski.v6i1.523
}

\section{Taufan Teguh Akbari ${ }^{1 *}$ Rizky Ridho Pratomo}

\author{
${ }^{1}$ LSPR Communication and Business Institute \\ Jl. K.H Mas Mansyur, Kav. 35, Jakarta 10220 - Indonesia \\ ${ }^{2}$ Pusat Studi Kemanusiaan dan Pembangunan \\ Jl. Cisokan I, No. 5 Abadijaya, Kec. Sukmajaya, Kota Depok 16417 - Indonesia \\ *Corresponding author: taufan.ta@1spr.edu
}

Submitted: January 29, 2021, Revised:March 13, 2021, Accepted: April 12, 2021

Accredited by Kemristekdikti No. 28/E/KPT/2019

\begin{abstract}
The Covid-19 pandemic has hit many sectors in the world. To mitigate the plague, many countries have formulated a social distancing policy. The pandemic compels us to foster the use of technology to carry out daily activities. A very few articles explain how technology alters the way leaders communicate. Therefore, the objective of this research is to examine whether technology has an impact on leader communication patterns using Adaptive Leadership and Technological Determinism Theory. This research uses qualitative approach with literature review and interview as a means to collect and analyze data. Based on the current trend, there are some changes in leader communication patterns. Also, the author found that there is a gap in the adoption of technology between leaders and members of the organization. While leaders are prepared to change mindset and embrace digital practices, members are not well-prepared. They struggle to adjust to the new work environment and feel overworked and exhausted. To embrace the digital working environment, leaders need to solve the gap. We argue that the gap between the leaders and members can be addressed by enhancing or improving the way leaders and members interact. This is because to become a leader, one should engage in communication. We propose some principles about new ways of communication during the New Normal.
\end{abstract}

Keywords: Technology; leadership; communication; new normal leadership; covid-19

\section{Introduction}

It is a common belief that technology has changed the fundamentals of social life, either in daily life or professional life. A concrete example is the global use of the internet and social media which has been growing steadily. The 2020 report compiled by We Are Social and Hootsuite found, there is 4,2 billion social media users across the world compared to 1,482 billion in 2012 . Meanwhile, in the organization, the society's increasing reliance on technology has a tremendous impact on the organization, in terms of structure, form and also widening the organization's strategic options to improve the performance (Abu Naser et al., 2018). Furthermore, the advancement of information communication technologies (ICTs) has provided a wealth of innovations around the way individuals work and communicate (Phelps, 2014). In sum, digitalization and the phenomenon of digital transformation are rapidly and fundamentally changing existing businesses and organizations alike (Sahjaya \& Rao, 2018).

When the pandemic comes, leadership best practices are challenged. Social distancing policy forces leaders to adopt new leadership practices and ICT's role and usage becomes more significant for the organization. Several technology platforms 
such as zoom and google meet are used for organizational coordination and communication needs. At the start of the pandemic, there is 300 million meeting participants in the zoom platform and 100 million in Google Meet (Barret, 2020).

One of the challenges to lead an organization during the pandemic is how to communicate in times of crisis. In terms of leadership communication, leaders' communication must be frequent, iterative, and must use multiple dissemination media (Stoller, 2020). It is important to maintain consistency, conveying facts, transparency in scientific information, and expressing sympathy, especially when dealing with a crisis (Paek \& Hove, 2021). In leadership practices, to lead effectively, managers should take a task-oriented behavior and allowing workers to have certain autonomy to adapt to the circumstances (Bartsch et al., 2020). There is also research that emphasizes transparency, walk-thetalk, and adaptive quality for the leader in the COVID-19 crisis (Forster et al., 2020). Among the many leadership lessons that emerge for us in light of the current crisis, communication makes it to the top of the list (Dirani et al., 2020).

While current research gave enlightenment about leadership quality and communication, much research gives too much focus on leadership practices and how to communicate in a crisis. There is one of the most vital aspects which is forgotten, that is how communication technology alters the approach of leaders to their employees, especially in the communication styles. The digital transformation has affected work-life and health, the use of information and communication technology, performance, and talent management, and organizational hierarchies (Schwarzmüller et al., 2018).

The ICT has lowering costs which cause heightened both access to, and the volume of, communication, and in myriad and sometimes important ways to its content and purpose. (Buzan \& Lawson, 2015). Looking for this perspective, ICT has facilitated people to do things effectively and efficiently. Although, there is a mixed impact on humanity in terms of communication. For example, mobile phones inhibited the development of interpersonal closeness and trust and reduced the extent to which individuals felt empathy and understanding from their partners (Przybylski \& Weinstein, 2013). Social media also has decreased the intensity of interpersonal communication (Husna, 2018). Some positive effect includes offering different possibilities and ways to engage with other and reduce social isolation (Khosravi et al., 2016). In the context of firm practices, ICT can lower a company's search and communication cost between the focal firm and their trading partners (Chen \& Kamal, 2016).

However, not much research is addressing how technology changes the way of human communication and leadership practices in the midst of the pandemic. When looking at the historical context, human thinking is more influenced by the advancement of technology. It is no different from the present when the presence of technology shapes our way of thinking. Even when the Covid-19 pandemic is over, the author argues that some communication practices will still survive for various reasons. Therefore, this research elaborates on the impact of technology on leadership communication style. The author also formulates how the adaptation is carried out by the leader and how is the leadership communication style in the New Normal.

\section{Theoretical Framework}

It is not easy to provide a definition of leadership that is universal and accepted by all parties involved in organizational life (Kaswan, 2019). Some argue that there is no universal definition is because the field of leadership studies is entrenched in a conceptual crisis that severely limits our understanding of leadership in contemporary organizations (DeRue, 2011). However, in this context, leadership is a problemsolving process in the midst of challenges, either in internal or external organizations.

Based on the above perspectives, there are two correlations that cause leaders to make an effort for adaptation and problem-solving. First, in the midst of many conditions of uncertainty, problems will continue to befall the organization as a result of these changes. Second, in solving these problems, a leader must transform and be required to continue to develop and be adaptive. As environmental factors continue to force organizations to adapt and change, researchers, practitioners, and leaders will be required to develop methods to more effectively handle the challenges of less predictability, increased uncertainty, and complexity surrounding such changes (Arthur-Mensah \& Zimmerman, 2017). Therefore, transformational consciousness begins with individuals and then spreads to other levels: groups, organizations and society (Šimanskienė \& Župerkienè, 2014).

However, contrary to general thinking, adaptive leaders do not adapt to change. Adaptation implies a response, a reaction to change; they anticipate change, prepare for it, and often make change happen in the direction they want to go (Govindarajan, 2016). That's an essential ability for individuals charged with 
leading their business or organization in this rapidfire millennium.

Following Govindarajan's argument, there must be some behavior prerequisite for a leader to be adaptive. Some concepts of Sustainable Leadership provide the first prerequisite for the leader to be adaptive. To be an adaptive leader, that is the need for transformational leadership as a driving force and necessary conditions for sustainable transformation and development (Tideman et al., 2013). From this, it follows that future leaders need to adopt practices in which they can discover and adopt new mindsets, beliefs, and attitudes and develop skills relevant to an unprecedented journey of transformational sustainability. The second is to understand the emotional toll and stress the entire process of change will have on followers as they are being asked to take up challenges which they may not be ready for. (Arthur-Mensah \& Zimmerman, 2017). Third, adapting to the new communication environment. In terms of communication, adaptive leadership communication is a condition where the leader adjusts the patterns and modes of communication and the media used. In Covid-19, leaders are looking for appropriate communication patterns based on developments in the situation and conditions of members.

\section{Technological Determinism}

Much criticism has been leveled against this concept. However, seeing its relevance to the times, technology has indeed become an agent of change itself. In general, technological determinism means that the existence of technology has a role in determining the social, economic, cultural, and political landscape. Technological determinism is approaches that emphasize (1) the autonomy of technological change and (2) the technological shaping of society (Dafoe, 2015).

The technological innovations that have occurred in the last few decades reinforce the argument that technology is changing the world. Klause Schwab argued that all new developments and technologies have one key feature in common: they leverage the pervasive power of digitization and information technology (Schwab, 2017). In a business context, Christensen calls it a technology disruption where technological innovation disrupts old businesses.

Different in the subject, McLuhan stated about how media or medium play a significant role in our society.

\footnotetext{
"Medium is reshaping and restructuring every aspect of our life including social
}

interdependence, thus, forcing us to rethink and reconsider the course of action and the way of thinking. Humanity has always been shaped by the nature of the media by which men communicate: from the alphabet to the internet. In other words, it is impossible to understand cultural and social change without understand the work of the media." (McLuhan \& Fiore, 1967: 9).

This fact merely underlines the point that "the medium is the message" because it is the medium that shapes and controls the scale and form of human association and action (McLuhan, 1994).

The writer uses this theory because it is relevant to the current situation where technology, which originally only served as an instrument has become deterministic. Technology have significant impact in shaping leaders communication styles and channels. The trend is expected to keep continue.

\section{Material and Methodology}

The author uses a qualitative approach. In a qualitative research, it is not just a matter of describing a phenomenon, so that the phenomenon is not "numbered", but the most important thing is explaining the meaning, describing the meaning of the phenomenon that appears, even explaining "meta-meaning" (Bungin, 2008).

The author uses the literature review method. The literature review can serve as a basis for knowledge development, create guidelines for policy and practice, provide evidence of an effect, and, if well conducted, can engender new ideas and directions for a particular field (Snyder, 2019). By summarizing, analyzing, and synthesizing a group of related literature, we can test a specific hypothesis and/or develop new theories (Xiao \& Watson, 2019). Alongside literature review, the author conducted interviews with practictioners from contemporary organizations, ranging from corporate bodies, start-ups, to educational institutions.

\section{Result and Discussion}

Why technology plays a vital role in human life? Of course, this question must be answered comprehensively. Does technology force people to change, to adopt new ways opened up by technological innovation? However, what does technology also need to explain to answer the questions above?

Regarding the meaning, it is still a matter of debate, but in the context, technology can be defined as a mode of being, a way of life, or a kind of thinking (Sikka, 2011). What Sikka means is not limited to technical aspects that are identical to technology but from the functional aspects as well. 
Technology, thus: (1) denotes those entities' artifacts, techniques, institutions, systems - that are or were functional, and (2) emphasizes the functional dimension of those entities (Dafoe, 2015).

For example, when Gutenberg invented a printing press that was put to good use by Martin Luther to spread his ideas of secularism. Printing machines can reproduce writing faster and massive. This also affects how it is distributed. At the time of King Darius during the expansion period, his kingdom used a line of men to shout to spread the word to other provinces, where the speed was 30 times faster than using runners.

Another example is how technology changes the flow of life when the existence of the telegraph triggered the joining of New York publishers to form the Associated Press. Associated Press makes use of the telegraph's ability to collect information remotely. Furthermore, the Associated Press built a 20th century model of mass communication in which they collect information remotely, curate it, and then distribute it to the public (Wheeler, 2019).

The examples above show how technology shapes mindsets and generates new ways of communicating. However, the impact of earlier technology was not as great as now where the internet appeared for global consumption. To the certain extent, current technology has been engineered to be able to fundamentally change socio-cultural, environmental, and biological life, from within and without (Sikka, 2011).

The internet brings communication into the digital space where everything is fast and instantaneous. The advent of technology such as computers, laptops, and smartphones made communication easy. "Once the user has acquired a computer or smartphone, and once the hardware and connection costs are met, then the costs of each communication act itself become very insignificant" (Madianou \& Miller, 2013). Advances in technology have simplified communication allowing multiple messages to be sent at minimum cost (Alhadlaq, 2016). Technology has helped communication to bridge distance and even time (Dutta \& Mehta, 2019).

More than that, the internet changes human behavior patterns, especially how humans communicate, both positive and negative. The existence of technology has diminished the sense of togetherness and reduced the intensity of friendship. She also emphasizes the technology creates a feeling of "loneliness" because matters are made easier thanks to technology so that there is no intensive interaction process between one person and another (Ngafifi, 2014).
Technology will continue to evolve, but the impact is already immense. This is of course a challenge for leaders to see how the phenomenon impacted society. Moreover, when it comes to the workforce demography, leaders are faced with the millennial generation and $\mathrm{Z}$ where they are in direct contact with and exposed to technology. The character of their communication in the workplace is that they want healthy, inclusive communication and are given good feed for growth (Hall \& Austin, 2016). One research found that the communication characteristics that the technology generation wants: face-to-face, open and two-way communication, straightforward, and mentor (Omilion-Hodges \& Sugg, 2019).

In an organizational context, this is a challenge for leaders how to use the right approach without reducing its meaning. Moreover, with the many demands and desires of the workforce, leaders must find the right approach. Unlike technology in previous centuries, technology today presents new challenges, which are more dynamic, unstructured, and erratic. Leaders must adapt to the fact that leaders can no longer rely on the traditional way, but must be hybridized, a combination of old and new ways.

However, while leaders are still adjusting their ways and styles towards their members who enter and leave the organization, the world is being attacked by the COVID-19 Pandemic and currently, a pandemic is still happening and affecting the public at large.

\section{Behavior and Leadership Challenge}

The pandemic forces leaders to change the way they think. To survive the pandemic, they must find new ways of doing activities and in the context of communication, how they coordinate and communicate with their members. Especially with the uncertainty of when the pandemic will end and even though vaccines are available, leaders must continue to find new ways. However, before that, the author wants to explain how leaders are aware of their integration with technology.

Communication challenges vary when examining the demographics of the workforce. Looking at Indonesia, according to the 2019 National Labor Force Survey, generation $\mathrm{X}$ numbered 59 million, of which 32 percent were permanent workers. Meanwhile, millennial generation (Y) numbered 48 million, of which 53 percent were permanent workers. Generation $\mathrm{Z}$ accounts for 12 million workers, of which 57 percent were permanent workers. After all, in the next decade, Generation X will leave the world of work so that in the future, millennials and generation $\mathrm{Z}$ will dominate the skilled labor 
market. Judging by this figure, communication challenges will vary, but this generation is quite adaptive to technology. Even so, working fully digital is a new experience. However, before Covid-19, the leader has tried to adopt technology for their communication needs. Research on corporate strategic communication found that employees were more likely to receive information from e-mail and communicated directly by their managers (Men, 2014). However, public relations executives prefer face-to-face communication which way it keeps employees informed and also feels safe in the company because they get information directly from their superiors (Mishra et al., 2014). Regardless of the communication channels, implicitly, in all generations, members or employees want transparency in communication (Yue et al., 2019). Transparent communication can increase employee trust, satisfaction, commitment, and feelings of empowerment (Men \& Stacks, 2014).

Above all, there is a fundamental need to adopt technology for leadership practice. It is a necessity to have a technological mindset for the company to thrive and survive in the competition. Some researchers conclude that the adoption of technology is a necessity so it is imperative to have technological capabilities (Akcil et al., 2017).

Based on the above arguments, according to the author, even before the pandemic, leaders had tried to adopt digital technology. However, for their full adoption, they still adapt to the nature of the technology itself. Is technology able to meet existing needs? Then, how are their colleagues or members able to make good use of technology. There are issues of digital literacy and whether technology can have an impact on interpersonal relationships between members. This is what the leader considers. In the context of pedagogy -if not all, the full adoption of technology will occur when leaders have an understanding of (1) locus of control of technology adopters; (2) power contestations between academics and students; (3) alignment of technology with pedagogical goals; and (4) shared intentionality between the core group of informal leaders (Rambe \& Dzansi, 2016).

Before the leaders can answer all the questions above, the pandemic arrived and presents a difficult challenge for both leaders and members, particularly how to coordinate and communicate digitally and without being face to face. Moreover, with the impact of the pandemic on business very critical, the only option is to adopt existing technology so that technology is no longer instrumental, but a determinant for the continuity of communication between the leader and the members themselves. Thus, working from home is the only best option.

There is only one thought according to the author in the minds of leaders during a pandemic: how to survive and continue in the process of achieving organizational goals. They have to go through this pandemic wave which consumes a lot of energy. The only way that can be done is by adopting technology, so there is a change in the way of thinking here where initially the leader sees technology as instrumental, then becomes determinant. Leaders who view technology become determinants due to pandemic conditions that make it impossible to work and coordinate with their members in normal situations. On the other hand, the business that he is involved in is in a bad condition.

Therefore, communication is carried out with media such as zoom, google meet, Whatsapp, and other media. Leaders are required to understand more about technology, better understand the conditions of their members, and adjust the way of communication as needed. One thing that characterizes a pandemic is a change in the work environment, both professional and organizational which also changes the pattern of communication between members. Above all, the role of the internet is becoming increasingly significant.

During the pandemic, the internet is the lifeblood of all activities, from communication to coordination. Its role is so large that without the internet, work is neglected, left out of information, and isolated. This means that the internet is a primary need for both leaders and members. Referring to the nature of the internet, coordination, and communication take place in real-time. The positive impact has been explained earlier that it not only reduces costs but also increases effectiveness in communicating. Even in the New Normal era, the internet will become a necessity.

Moreover, after a year of struggling with the Covid-19 situation, leaders have felt that digitalization has become a requirement for the organization to succeed. For companies, adopting communication technology has several advantages: (1) it is easy and fast to use, (2) it can review and improve the messages conveyed, (3) it can communicate with people all over the world, and (4) it increases work flexibility (Maarit Lipiäinen et al., 2014).

Furthermore, more companies nowadays tend to adopt technology and encourage their members to think like technologist in the future. Data from Accenture says that $86 \%$ of corporate executives agree that their organizations should train their members to think like technologists to use and 
adapt technology to individual needs even without high technical skills. In addition, the impact of implementing such an organizational system is the possibility of permanently implementing work from home. Twitter started to build work from home policy a few years ago and the Japanese technology company, Fujitsu, started the same. They let their members decide whether they want to work at home or in the office. Returning to the office turned out to be optional, not permanent (Accenture, 2021).

For leaders, technology adoption can solve solutions related to coordination and communication. However, for members, the effect can be different, especially when it comes to interpersonal relations. It has a mixed feeling whether members should accept the full adoption of technology to their organizations without losing the benefit of traditional communication.

\section{Contrary Effect to Organization Members}

The effect of technology adoption between leaders and members is certainly different (Table 1). From the leader's point of view, technology provides endless possibilities. Fully digitalized operationalization will make all aspects more efficient and able to compete in a market that is currently much more competitive than before. Therefore, leaders are competing to restructure their organizational and business models.

\begin{tabular}{cllll}
\multicolumn{5}{c}{ Table 1. Global and Indonesia Internet and Social Media Usage } \\
Year & \multicolumn{1}{c}{ Internet Users } & Social Media Users \\
& Global & Indonesia & Global & Indonesia \\
2015 & 3.010 Billion & 72,7 Million & 2.078 Billion & 72 Million \\
2016 & 3.419 Billion & 88,1 Million & 2.307 Billion & 79 Million \\
2017 & 3.773 Billion & 132,7 Million & 2.789 Billion & 106 Million \\
2018 & 4.021 Billion & 132,7 Million & 3.196 Billion & 130 Million \\
2019 & 4.338 Billion & 150 Million & 3.484 Billion & 150 Million \\
2020 & 4.540 Billion & 175,4 Million & 3.800 Billion & 160 Million \\
2021 & 4.660 Billion & 202,6 Million & 4.200 Billion & 170 Million \\
Source: Hootsuite and We Are Social & & &
\end{tabular}

In plain view, people have used social media for the benefit of communication and information exchange. The figure has tended to increase over the past seven years, both on a global and national scale. The increase is relatively stable, around 9-10 million users per year, although, from 2016-2018, the increase is sharp compared to internet users. In fact, in 2021, the number of internet users increases significantly to 202.6 million. That is, in terms of technology as a communication medium, the mindset has recognized that technology is changing their communication patterns. This does not only apply in Indonesia but throughout the world as well.

The utilization of technology in society has been seen in various cases, communication technology has been used for various activities. For example, social media is used to organize protests and communicate the public interest. New social movements are no longer a new thing when using social media as a medium to drive public participation and public opinion (Muqsith et al., 2019).

However, there is a contrasting fact that society will tend to adopt technology easier because of their frequent usage in digital communication channels. In the professional environment, members much prefer traditional media as main communication channels rather than digital. Research with demographics of generations
$\mathrm{X}$ to $\mathrm{Z}$ found that when members were asked about their communication preferences to discuss with managers, discussion forums and meetings were still the main choices (Tkalac Verčič \& Špoljarić, 2020). Although they said that there was no need to adopt new communication technology, however, basically, the members preferred face-to-face communication. Employees prefer to use face-toface communication with their leaders and want more frequency, even though their leaders communicate face-to-face (Braun et al., 2019). Then, there is an inverse pattern utilizing communication via email and telephone where even though the percentage is only $14 \%$, the members do not show interest in this communication medium (Braun et al., 2019).

According to the author, this implies that members do not want their professional communication channels to get mixed with their private digital channels. Members are still eager to find intimacy and closeness in their work environment. Therefore, they prefer to talk and communicate face-to-face. It is also a fact that cannot be denied that technology is unable to compensate for the benefits that face-to-face communication provides. Technology only plays a role in disseminating information, not building relationships. Moreover, humans need physical contact to feel a deeper connection and be able to read facial expressions. Put in context, one research 
found that $92 \%$ of respondents believe that the presence of technology negatively impacts face-toface communication (Drago, 2015).

When it comes to a large number of social media users and communication channels in the professional world, members provide clear boundaries between their professional and personal lives. Therefore, they do not want all sectors of life to use digital communication as a funnel to communicate. The so-called digital native generation has this attitude. A pilot study revealed that they prefer traditional media as their communication channel in the business world (Friedl \& Verčič, 2011). Therefore, the general trend of greater electronic communication was not perceived positively as the communication of choice between leader and employee. (Braun et al., 2019).

This shows the difference in attitudes between the leader and its members where the leader is ready to have a technological mindset, while those under him do not prefer to digitalize communications. They don't want to sacrifice the benefits of face-to-face communication. There is too much benefit from traditional communication which technology cannot imitate or even replace. Face-to-face communication allows reading of nonverbal communication such as cues, facial expressions, and the ability to respond immediately, also physical presence empowers communication and leads to greater collaboration, causing ideas to flow more freely (Nickitas, 2019). And of course, members do not want the ubiquitous presence of technology in our lives to limit opportunities to develop deep levels of selfawareness and behave authentically (Colbert et al., 2016). Besides, the above arguments also show that the members like structured communication and with a clear schedule. This shows how the members like order in communication so as not to waste energy.

Therefore, during the pandemic when everything is going digital, the members looked difficult to adapt to the massive digital work pattern. They become more isolated and disconnected from their social life. Based on the Microsoft Work Trend Index 2021, workers are still struggling to adapt to new conditions and work patterns. Additionally, because digital communication allows real-time, communication patterns are unstructured, with 62 percent of team meetings and calls being random and transient. And this makes the members feel a lot of pressure with such coordination and communication patterns (Microsoft, 2021).

There is interesting finding regarding the condition of members from generation $\mathrm{Z}$.
Generation Z, frontline workers, working moms, and a new employer are far struggling than millennials, $\mathrm{X}$, and boomer generation who have occupied a better and more established position in comparison. Differences in the level of struggling can occur due to various factors, ranging from career positions to large responsibilities at home and work. Also, 37 percent of the global workforce felt that companies were asking them too much (Microsoft, 2021).

Another problem is related to mental health issues. The pandemic brings psychological problems that worry many parties. Moreover, with Covid-19 which can easily infect anyone coupled with social restriction policies, it creates bad psychological problems.

The Indonesian Society of Mental Medicine Specialists findings are very worrying. From 5661 people, 68 percent experienced psychological problems and of the 2606 self-examiners, 67.4 percent experienced symptoms of anxiety. Even from 2294 self-examiners, as many as 67.3 percent experienced depression and 48 percent of respondents said they wanted to hurt themselves and it would be better to die. In the context of psychological trauma, out of 761 self-examiners, 74.2 percent experienced symptoms of psychological trauma with complaints of being constantly alert and feeling isolated. What is more worrying is that these symptoms are experienced by productive young people, namely those under 30 years of age (Andriani, 2020).

According to the author, this mental health problem presents its challenges, especially in the technological era. Policies of social distancing and vigilance against Covid-19 cannot be avoided, but isolated problems provide a conclusion on how technology is unable to solve problems of solitude. With work and social interactions turning almost entirely to the digital world, the use of technology is inevitable. However, agreeing with Nickitas, there are too many advantages to traditional communication patterns.

However, one positive thing from this pandemic period is that workers like to work flexibly. Even though it happened because of the pandemic conditions that required working at home, the trend that shows that companies will digitize the way they work in the future means that they have to choose between having a technological mindset or maintaining their old ways. Between structured and unstructured communication.

\section{Embracing New Condition for Leaders}

When it comes to the adaptability of leaders, it does not only show how leaders respond to 
changes in the external environment such as the influence of technology. However, member factors also influence the leader's attitude towards change. However, the leader must also change his mindset before implementing the changes made to his members. Seeing this, the trend shows that there is a change in the mindset of the leader himself.

The report from Accenture says that today's leaders are turning to build a digital infrastructure that will allow them to simultaneously transform many parts of their company (Accenture, 2021). The company is also building a work-from-home culture in which returning to the office becomes an option that is not imperative. Moreover, if you want to survive and progress, do not depend on the office as a place to collaborate, connect, and build social capital (Microsoft, 2021).

However, some problems must be addressed first. From the explanation above, it is found that the level of technology adoption between the leader and its members experiences inequality in mindset. When the leader is ready, the members are not ready yet proven by being tired and feeling overworked. This gap needs to be accommodated properly.

Examined the problem of the digital divide in work more carefully, one of the factors in this digital divide is a lack of communication between members and leaders. Adaptation does require a process where leaders can see the shortcomings of digitalization methods, especially how to communicate, cooperate and coordinate. However, this does not mean that it is a reason to forget the most important aspects of leadership itself.

Fully 85 percent of your success as a leader will be determined by your ability to communicate effectively with others (Tracy, 2010). He emphasized that the quality of communication that a person has determined the quality of life and relationships in the future. Being human means being involved in communication and to lead means to communicate (Ruben \& Gigliotti, 2016). Within the context, leaders need to find how they will communicate to their members in the new condition.

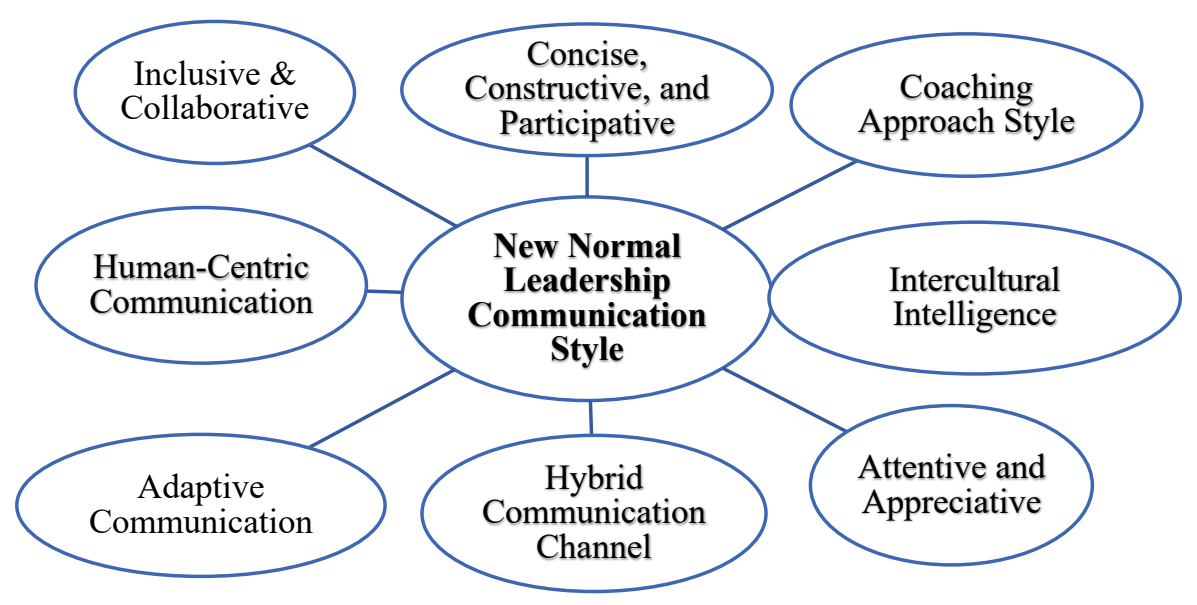

Figure 1. New Normal Leadership Communication Styles

The challenge of digitalization is in communication skills. Digitalization will dehumanize leadership practices that challenge leaders to create trust and lead a change (Jakubik \& Berazhny, 2017). In the context of leadership communication (Figure 1), adaptive leaders are those who can humanize their members and use various media to interact. Leaders also recognize the importance of humanist communication. Moreover, in an era where business leaders have a technological frame of mind that is an aspect that affects performance, communication between leaders and members becomes more vital.

Leaders need to go a step further than just recognizing the importance of communication networks: they also need to address the demands and opportunities of the digital age (Hayashi \& Soo, 2012). However, on top of that, leaders need to engage more with their members as face-to-face communication diminishes in the future. Therefore, it is essential to change the management paradigm from the one who sees humans only as a means of production in the direction that sees humans as the primary resource in the production of output (Amir, 2019).

Based on the concept we present in this article, the circumstance that is facing us, and the upcoming trend in the latest work principle, we believe that these principles are important for academic and practical purposes. In regard to the New Normal condition and work that begins to be more remote, the organization has tremendous 
opportunity to pool the talent across the world. The consequence is that remote work creates a diverse environment with various backgrounds: different reasons, ideology, belief system, family, ethnic, personal experience, etc. Therefore, the first principle is that all leadership communication is intercultural (Ruben \& Gigliotti, 2016).

Digital openness makes members demand transparency and involvement in organizational decision-making. Involving members is also an effort to keep them feeling "connected" and part of the team. At some point, Andy Saladin from SSS communications said that it is better to over communicate during this time. In other words, leaders need to communicate concisely, constructive and involve members' participation in the decision-making process.

Taking into account how work patterns will be mixed (online and offline), leaders must realize how important it is to be able to communicate with various media, especially digital. Head of Corporate Communications Astra International Tbk, Boy Kelana Soebroto stated that in Astra we enhanced the communication channel: "We are strengthening digital communication channels so that they can communicate effectively with stakeholders during the new normal and collaborating with parties who have the same vision in order to accelerate the achievement of corporate communication goals".

Leaders also need to give attention and appreciation in many opportunities. Muhammad Fikri from Community Partnership - Facebook Asia Pacific stated that: "The most important thing is that health and sanity take precedence during this new normal. Patterns of communication that are open, listen to each other and empower each other". Leaders and members are inseparable. In any situation, members also want to receive attention and appreciation from their leader. It is the deepest need in human nature that is to feel valuable and important (Tracy, 2010). Leaders must do everything they can to make members feel valued and increase their self-esteem at the same time.

One of the important aspects of communication in the New Normal era is a humanized approach to communication which put emphasis on empathy. Humanizing means, even during a crisis where businesses can collapse and have to pursue targets, it is very important to pay attention to the health and sanity side of its members. CEO BRI Danareksa Sekuritas, Friderica Widyasari stated that: "Empathetic leadership, at the time of this pandemic, it seems the most appropriate, because the situation is not normal in general". This is because, there is the greatest risk when the leader does not pay attention to the condition of its members.

This condition is well explained by Wafa Taftazani, Co-Founder of Modal Rakyat and Google APAC Lead Partnership Indonesia: "From a leadership perspective, the biggest risk during this pandemic is that we become "tone-deaf", insensitive to the difficulties/personal matters that the team is facing and continue to demand everything work-related".

Another principle of leader communication in the New Normal era is the importance of a leader to become a coach for his members. Seeing the fact that there are still many members who have difficulty adapting to the digital way of working, leaders need to be close and become friends with their members and monitor the process of cultural adaptation proactively. Chairman of Iblam Law School, Rahmat Dwi Putranto have similar stance: "A leadership approach that is assertive in making decisions, open/participative in taking considerations and input from various important stakeholders and methods of leaders who work like coaches for their employees". In LP3I (Education Institution of Profession Development Indonesia), this method has been applied according to Mahanugra Kinzana, CEO of LP3I: "We strengthen coordination. All teams are required to meet once a week. And 1 on 1 coaching is a new culture that every leader must do to his team".

In a New Normal situation, it is important for leaders to adopt an inclusive and collaborative way of working. Involve all members so that they feel valued and have a purpose. The most important part of this way of working is the giving of trust. This has been expressed by Achmad Aditya from Unilever Indonesia: "Instructive leadership and communication patterns are required to be delegative, so that the team must be able to move independently with the general direction of the leader." Ario Dimas, Vice President of Loket and Gojek also emphasize the important of delegation: "During New Normal. the leadership patterns that should be applied are trust-based delegation patterns, application of short-term goals, and innovation-based decisions".

\section{Conclusion}

The pandemic has accelerated digitalization process by creating a new work environment trend that leads leaders to think that technology is a deterministic factor so they must adopt digital technology, either voluntarily or compulsively. The contrasting fact is that leaders are better prepared than members indicates a different deterministic level of technology. When the leader is ready, the members have to struggle. This creates 
challenges that must be resolved to welcome a new era in business. These situations is imperative for leaders to change their communication styles.

This article has practical benefits where the author formulates several communication styles for leaders in the New Normal era seeing the level of technology adoption and the current situation. The drawback is that this research departs from literature studies, therefore, it demands to examine qualitatively the level of adoption and the mindset of leaders. On the other hand, it is also necessary to conduct a quantitative research about the level of technology adoption, especially in the aspect of communication and its effects on members.

\section{References}

Accenture. (2021). Technology Vision 2021: Leaders Wanted Master of Change at a Moment of Truth. Dublin: Accenture.

Abu Naser, S. S., El Talla, S. A., Al Shobaki, M. J., Ahmad, H. R., \& Abu-Naser, S. S. (2018). Information Technology Role in Determining Communication Style Prevalent Among AlAzhar University Administrative Staff. International Journal of Information Technology and Electrical Engineering. 7(4). https://hal.archives-ouvertes.fr/hal-02111495

Akcil, U., Aksal, F. A., Mukhametzyanova, F. S., \& Gazi, Z. A. (2017). An examination of open and technology leadership in managerial practices of education system. Eurasia Journal of Mathematics, Science and Technology Education, 13(1), 119131.https://doi.org/10.12973/eurasia.2017.00 $607 \mathrm{a}$.

Alhadlaq, I. (2016). How Technology Influences Communication. International Journal of Scientific \& Engineering Research, 7(1), 960963.

Amir, D. A. (2019). The Effect Of Servant Leadership On Organizational Citizenship Behavior: The Role of Trust in Leader as a Mediation and Perceived Organizational Support as a Moderation. Journal of Leadership in Organizations, 1(1), 1-16. https://doi.org/10.22146/jlo.42946.

Andriani, D. (2020, October 14). Masalah Kesehatan Jiwa Menjadi Penting Selama Masa Pandemi. Retrieved from lifestyle.bisnis.com:

https://lifestyle.bisnis.com/read/20201014/10 6/1304973/masalah-kesehatan-jiwa-menjadipenting-selama-masa-pandemi

Arthur-Mensah, N., \& Zimmerman, J. (2017). Changing Through Turbulent Times - Why Adaptive Leadership Matters. The Journal of Student Leadership;

$1(2)$. https://journals.uvu.edu/index.php/js1/article/ view/44.

Barret, B. (2020, November 8). How Google Meet Weathered the Work-From-Home Explosion. Retrieved from Wired.com: https://www.wired.com/story/how-googlemeet-weathered-work-from-home-explosion/

Bartsch, S., Weber, E., Büttgen, M., \& Huber, A. (2020). Leadership matters in crisis-induced digital transformation: how to lead service employees effectively during the COVID-19 pandemic. Journal of Service Management, 32(1), 71-85. https://doi.org/10.1108/JOSM05-2020-0160

Braun, S., Hernandez Bark, A., Kirchner, A., Stegmann, S., \& van Dick, R. (2019). Emails from the Boss - Curse or Blessing? Relations Between Communication Channels, Leader Evaluation, and Employees' Attitudes. International Journal of Business Communication, 56(1), 50-81. https://doi.org/10.1177/2329488415597516

Bungin, B. (2008). Penelitian Kualitatif: Komunikasi, Ekonomi, Kebijakan Publik, dan Ilmu Sosial Lainnya. Rawamangun: Kencana Prenada Media Group.

Buzan, B., \& Lawson, G. (2015). The Global Transformation: History, Modernity, and the Making of International Relations. Cambridge: Cambridge University Press.

Chen, W., \& Kamal, F. (2016). The impact of information and communication technology adoption on multinational firm boundary decisions. Journal of International Business Studies, $\quad 47(5)$, 563-576. https://doi.org/10.1057/jibs.2016.6.

Colbert, A., Yee, N., \& George, G. (2016). The digital workforce and the workplace of the future. Academy of Management Journal. 59(3), 731-739. https://doi.org/10.5465/amj.2016.4003

Dafoe, A. (2015). On Technological Determinism. Science, Technology, \& Human Values, 40(6), 1047-1076. https://doi.org/10.1177/0162243915579283.

DeRue, D. S. (2011). Adaptive leadership theory: Leading and following as a complex adaptive process. Research in Organizational Behavior. 31, 125-150. Elsevier.https://doi.org/10.1016/j.riob.2011.0 9.007.

Dirani, K. M., Abadi, M., Alizadeh, A., Barhate, B., Garza, R. C., Gunasekara, N., Ibrahim, G., \& Majzun, Z. (2020). Leadership competencies and the essential role of human resource development in times of crisis: a response to Covid-19 pandemic. Human 
Resource Development International, 1-15. https://doi.org/10.1080/13678868.2020.1780 078

Drago, E. (2015). The Effect of Technology on Face-to-Face Communication. In Elon Journal of Undergraduate Research in Communications.

6(1). http://www.inquiriesjournal.com/a?id=1137.

Dutta, S., \& Mehta, N. (2019). Role of Immersive Technology in the Business Communication Today. International Journal of Research in Business Studies. 4(2), 17-26.

Forster, B. B., Patlas, M. N., \& Lexa, F. J. (2020). Crisis Leadership During and Following Covid-19. Canadian Association of Radiologists Journal. 71(4), 421-422. SAGE Publications Inc. https://doi.org/10.1177/0846537120926752.

Friedl, J., \& Verčič, A. T. (2011). Media preferences of digital natives' internal communication: A pilot study. Public Relations Review, 37(1), 84-86. https://doi.org/10.1016/j.pubrev.2010.12.004.

Govindarajan, V. (2016). Adaptive Leadership 101. Leader to Leader. 81, 42-46. https://doi.org/10.1002/lt1.20244.

Hall, A., \& Austin, S. F. (2016). Exploring The Workplace Communication Preferences of Millennials. Journal of Organizational Culture. 20(1), 1-19.

Hayashi, C., \& Soo, A. (2012). Adaptive Leadership in Times of Crisis. PRISM, 4(1), 78-86. http://www.jstor.org/stable/26469795.

Husna, N. (2018). Dampak Media Sosial terhadap Komunikasi Interpersonal Pustakawan di Perpustakaan UIN Sunan Kalijaga Yogyakarta. Libria. 9(2). https://www.jurnal.arraniry.ac.id/index.php/li bria/article/view/2400

Jakubik, M., \& Berazhny, I. (2017). Rethinking Leadership and Its Practices in the Digital Era . Management International Conference, 471483.

Kaswan. (2019). Kepemimpinan Dampak dan Warisannya: Praktik Kepemimpinan untuk Meraih Keunggulan Organisasi Jangka Pendek dan Jangka Panjang. Bandung: Alfabeta.

Kaul, V., Shah, V. H., \& El-Serag, H. (2020). Leadership During Crisis: Lessons and Applications from the COVID-19 Pandemic. Gastroenterology, 159(3), 809-812.

Khosravi, P., Rezvani, A., \& Wiewiora, A. (2016). The impact of technology on older adults' social isolation. Computers in Human Behavior. 63, 594-603. Elsevier Ltd. https://doi.org/10.1016/j.chb.2016.05.092.
Maarit Lipiäinen, H. S., Karjaluoto, H. E., \& Nevalainen, M. (2014). Digital channels in the internal communication of a multinational corporation. Corporate Communications, 19(3), 275-286. https://doi.org/10.1108/CCIJ-07-2012-0050.

Madianou, M., \& Miller, D. (2013). Polymedia: Towards a new theory of digital media in interpersonal communication. International Journal of Cultural Studies, 16(2), 169-187. https://doi.org/10.1177/1367877912452486.

McLuhan, M. (1994). Understanding Media: The Extension of Men. Massachusetts: The MIT Press.

McLuhan, M., \& Fiore, Q. (1967). The Medium is the Message: An Inventory of Effects. California: Gingko Press Inc.

Men, L. R. (2014). Strategic Internal Communication. Management Communication Quarterly, 28(2), 264284.https://doi.org/10.1177/08933189145245 36.

Men, L. R., \& Stacks, D. (2014). The Effects of Authentic Leadership on Strategic Internal Communication and Employee-Organization Relationships. Journal of Public Relations Research, 26(4), 301324.https://doi.org/10.1080/1062726X.2014. 908720.

Microsoft. (2021). 2021 Work Trend Index: The Next Great Disruption Is Hybrid Work - Are We Ready? Washington: Microsoft.

Mishra, K., Boynton, L., \& Mishra, A. (2014). Driving Employee Engagement: The Expanded Role of Internal Communications. International Journal of Business Communication, 51(2), 183202.https://doi.org/10.1177/23294884145253 99.

Muqsith, M. A., Muzykant, V. L., \& Kuzmenkova, K. E. (2019). Cyberprotest: new media and the new social movement in Indonesia. Journal of Studies in Literature and Journalism, 24(4), 765-775. https://doi.org/10.22363/23129220-2019-24-4-765-775.

Ngafifi, M. (2014). Kemajuan Teknologi dan Pola Hidup Manusia dalam Perspektif Sosial Budaya. Jurnal Pembangunan Pendidikan: Fondasi dan Aplikasi, 2(1). https://doi.org/10.21831/jppfa.v2i1.2616.

Nickitas, D. M. (2019). First-Face Communication: Is Digital Technology Impacting Leadership Communication Effectiveness? Nursing Economics (37) (2), 65-66.

Omilion-Hodges, L. M., \& Sugg, C. E. (2019). Millennials' Views and Expectations 
Regarding the Communicative and Relational Behaviors of Leaders: Exploring Young Adults' Talk About Work. Business and Professional Communication Quarterly, 82(1), $\quad 74$ 100.https://doi.org/10.1177/23294906188080 43.

Paek, H.-J., \& Hove, T. (2021). Information Communication Technologies (ICTs), Crisis Communication Principles and the COVID19 Response in South Korea. Journal of Creative Communications. https://doi.org/10.1177/0973258620981170.

Phelps, K. C. (2014). So Much Technology, So Little Talent? Skills for Harnessing Technology for Leadership Outcomes. Journal of Leadership Studies, 8(2), 51-56. https://doi.org/10.1002/jls.21331.

Przybylski, A. K., \& Weinstein, N. (2013). Can you connect with me now? How the presence of mobile communication technology influences face-to-face conversation quality. Journal of Social and Personal Relationships, 30(3), 237246.https://doi.org/10.1177/02654075124538 27.

Rambe, P., \& Dzansi, D. Y. (2016). Informal distributed leadership in technology adoption. African Journal of Science, Technology, Innovation and Development, 8(2), 155-165. https://doi.org/10.1080/20421338.2016.1147 200.

Ruben, B. D., \& Gigliotti, R. A. (2016). Leadership as Social Influence. Journal of Leadership \& Organizational Studies, 23(4), 467-479. https://doi.org/10.1177/1548051816641876.

Sahjaya, C., \& Rao, K. S. (2018). New Leadership in the Digital Era: A Conceptual Study on Emotional Dimensions in Relations With Intellectual Dimensions. International Journal of Civil Engineering and Technology. 9(1), 738-747.

Schwab, K. (2017). The Fourth Industrial Revolution. New York: Crown Business.

Schwarzmüller, T., Brosi, P., Duman, D., \& Welpe, I. M. (2018). How does the digital transformation affect organizations? Key themes of change in work design and leadership. Management Revue, 29(2), 114138. https://doi.org/10.5771/0935-99152018-2-114.
Sikka, T. (2011). Technology, communication, and Society: From Heidegger and Habermas to Feenberg. Review of Communication, 11(2), 93-106. https://doi.org/10.1080/15358593.2010.5517 81.

Šimanskienè, L., \& Župerkienè, E. (2014). Sustainable leadership: the new challenge for organizations. Forum Scientiae Oeconomia, 2(1), 81-93. http://ojs.wsb.edu.pl/index.php/fso/article/vie $\mathrm{w} / 103$

Snyder, H. (2019). Literature review as a research methodology: An overview and guidelines. Journal of Business Research, 104, 333-339. https://doi.org/10.1016/j.jbusres.2019.07.039.

Stoller, J. K. (2020). Reflections on leadership in the time of COVID-19. BMJ Leader. 4(2), 7779. https://doi.org/10.1136/leader-2020000244.

Tideman, S. G., Arts, M. C., \& Zandee, D. P. (2013). Sustainable Leadership: Towards a Workable Definition. The Journal of Corporate Citizenship, 49, 17-33. http://www.jstor.org/stable/jcorpciti.49.17

Tkalac Verčič, A., \& Špoljarić, A. (2020). Managing internal communication: How the choice of channels affects internal communication satisfaction. Public Relations Review, $\quad 46(3), \quad 101926$. https://doi.org/10.1016/j.pubrev.2020.101926

Tracy, B. (2010). How the Best Leaders Lead: Proven Secrets to Getting the Most Out of Yourself and Others. New York.

Wheeler, T. (2019). From Gutenberg to Google: The History of Our Future. Washington: Brooking Institution Press.

Xiao, Y., \& Watson, M. (2019). Guidance on Conducting a Systematic Literature Review. Journal of Planning Education and Research, 39(1), 93-112. https://doi.org/10.1177/0739456X17723971.

Yue, C. A., Men, L. R., \& Ferguson, M. A. (2019). Bridging transformational leadership, transparent communication, and employee openness to change: The mediating role of trust. Public Relations Review, 45(3). https://doi.org/10.1016/j.pubrev.2019.04.012. 